\title{
XLI. On a pseudomorphous variety of iodide of potassium
}

\author{
Robert Kane M.D. M.R.I.A.
}

To cite this article: Robert Kane M.D. M.R.I.A. (1840) XLI. On a pseudomorphous variety of iodide of potassium , Philosophical Magazine Series 3, 16:102, 222-224, DOI: $10.1080 / 14786444008650025$

To link to this article: http://dx.doi.org/10.1080/14786444008650025

册 Published online: 01 Jun 2009.

Submit your article to this journal $[\pi$

Џ Article views: 2

Q View related articles $\asymp$ 
ving been employed chiefly by the geometers. This explains why Boetius introduced that passage into his treatise on geometry; and in his treatise on arithmetic, which treats on the properties of numbers, no mention of it is made. This latter work is indeed only a new version of the treatise by Nicomachus on the same subject."

This ought to be compared with what has been stated in the number of this Magazine for December, and it will be seen that it is quite destructive of M. Libri's principal argument. I may add, in corroboration of the opinion of $\mathbf{M}$. Chasles, that Abelard's tract in the Leyden library is entitled de Doctrina Abaci vel radii Geometrici; the manuscript itself is thus described in the printed catalogue:- "Adolardus, qui statim in principio dicitur philosophorum assecla ultimus, de doctrina abaci, vel radii geometrici, ut ipse scribit quoque vocari. In fine legitur, Regularum abaci nobilis arithmetici tractatus explicit feliciter."

And now a word with M. Libri. When he says, "Si l'opinion de M. Halliwell avait été aussi explicite que le pense le savant géomètre de Chartres, il semble qu'on n'aurait pas dû employer plusieurs pages pour ticher de le prouver," he had forgotten that the plusieurs pages were the produce of his own pertinacity. When I had explicitly stated that the Bodleian manuscripts indicated a knowledge of the value of local position, and that one of them actually made use of the sipos, surely no one could reasonably accuse me of withholding my assent from the explanation given by $M$. Chasles. Much less, in that case, could there have been a necessity for occupying the attention of two meetings of the Institute on a mere question of opinion.

XLI. On a Pseudomorphous variety of Iodide of Potassium By Robert Kane, M.D., M.R.I.A.

DRING the crystallization of a large quantity of iodide of potassium, in the manufacturing laboratory of Apothecaries' Hall, I observed a large group of long prisms to be formed, of great lustre and regularity. These prisms were in many cases terminated by four-sided pyramids, formed by the joining of four rhomboidal planes, by which the solid angles of the prism were replaced; and I succeeded in obtaining a series of specimens, in some of which the prism was simple and terminated by a single plane perpendicular to its axis; in others the solid angles were replaced by very minute triangular planes, rendering the terminal plane octagonal, and finally, as the triangular planes increased in size, square, the diagonals of the square being parallel to the sides of the 
original surface, and hence the gradual conversion of the replacing triangles into rhombs, which effacing the terminal plane formed the pyramidal summit already noticed.

The prisms are straight, with square bases. The replacing triangular or rhomboidal planes form with the lateral edges, to which it is inclined, an angle of $150^{\circ}$, and with the terminal plane an angle of $120^{\circ}$ : its angles with the vertical and horizontal axes of the crystal being therefore $60^{\circ}$ and $30^{\circ}$, giving the ratio of the axes therefore as $1: 1 \cdot 73$. The angle formed by two adjacent rhomboidal planes of the pyramid was found to be $105^{\circ}$, and that of the summit formed by two opposite rhomboidal planes was $60^{\circ}$. The angle across the summit, measured on the edges of the rhomboidal planes, was $80^{\circ}$, and that of a rhomboidal plane, on the adjacent side, was $140^{\circ}$. The angles of the rhomboidal plane were $60^{\circ}$ and $120^{\circ}$.

In these measurements I could not obtain greater accuracy than within a degree, from the circumstance that the replacing surfaces were not, in reality, planes, but portions of spherical or at least curved surfaces of great radius, so that the adjacent edge had different inclinations to different portions of the rhombic surface. In addition to this peculiarity, other marks of a complex or macled structure were very evident. The smaller crystals, although equally well marked as to form and replacements with the larger, differed from them in being wholly clean and transparent. The larger ones, on the contrary, consisted of three distinct portions, the external being a hollow shell of perfectly transparent material, the next being a core of opake white substance, apparently porous and granular, as if formed of a congeries of minute crystals independent of the case in which they were contained, whilst in the centre there was to be seen a delicate but well-defined transparent rectangular cross, the arms of which generally penetrated quite through the opake substance and united with the external transparent shell.

A section of such a crystal had in fact the appearance represented in the little sketch, the white opake portion being shown shaded.

These crystals possessed single refraction. They had no action on polarized light transmitted along their axis; and hence, although with a pyramid belonging to the square prismatic system, they belonged really to the regular system, by a congeries of minute crystals (probably cubes) of which they must be formed. In solubility they were the same as the common iodide of potassium, with which their composition likewise identified them. From their 
having formed on the top of a large cross of common crystals, they must have been generated under circumstances either on a lower temperature or a less concentrated solution than that by which the common variety is produced. If the newformed crystals be dissolved in water, it is under the ordinary form that they recrystallize.

When iodide of potassium is crystallized in leaden or tinned iron vessels, Mr. Scanlan has informed me that the crystalline form is altered, from the presence of a minute quantity of iodide of tin or lead; but what the alteration is exactly, 1 do not believe has been determined. Having heard the fact, however, from my friend $\mathrm{Mr}$. Scanlan, I sought for metallic impurity in the crystals now described, but in vain. They are chemically pure.

\section{Proceedings of Learned Societies.}

ROYAL IRISH $\Lambda$ CADEMY.

Nov. 11, R EV. Dr. Dickinson gave a verbal account of a remark1839. I able waterspout, which he had observed at Killiney during the last summer.

Towards the end of the month of July, about 10 A. M., while standing on the shore of the bay of Killiney, his attention was directed by a friend to a waterspout, distant about a quarter of a mile from the land. It was not similar in form to the representations of waterspouts usually given, and may therefore deserve to be noticed. It was shaped like a double siphon, the whole being suspended at a considerable elevation in the air; the longer end of the siphon reached towards the sea, and appeared to approach it nearer and nearer, till, at length, its waters were distinctly seen rushing into the deep. The loop gradually lowered, as if sinking and lengthening by its own weight, while the upper part of the siphon seemed not to lose in elevation. At length the loop burst, and there were three streams of water pouring into the sea, two of those streams still continuing united by the arch at the top. The breadth of these streams gradually diminished till they became invisible, but their length seemed undiminished as long as they were at all seen. The quantity of water poured down must have been very considerable, as the bubbling of the sea beneath could be distinctly observed.

Dr. Dickinson was informed that a waterspout fell a few days after inland, towards the Three-Rock mountain. It is said to have done some injury; but his informant did not see it, and he could not, therefore, ascertain its shape.

November 30, 1839.. Mr. Clarke read a paper "On Atmospheric Electricity."

The anthor commenced his paper with a description of the apparatus which he had employed in the experimental investigation of this subject. He showed the inapplicability of the electrometers 